\title{
The Ecology Center: Organizational Structure, Leadership, and the Environmental Movement
}

MIKE SHRIBERG ${ }^{1,2^{*}}$, HILLARY BEDEIAN ${ }^{1}$

Volume 2, Fall 2014

http://dx.doi.org/10.3998/mjs.12333712.0002.005

${ }^{1}$ Graham Sustainability Institute, University of Michigan, 625 E. Liberty Street, Suite 300, Ann Arbor, MI 48104

2Program in the Environment \& Earth and Environmental Sciences,

University of Michigan, 1120 Undergraduate Science Building,

204 Washtenaw Ave, Ann Arbor, MI 48109

${ }^{*}$ Corresponding Author: Mike Shriberg, mshriber@umich.edu

\section{ABSTRACT}

In 1970, the University of Michigan held the first major Earth Day celebration. Organizers used excess funds to create a new independent non-profit, as did organizers of many other Earth Day events across the country. Forty-four years later, Ann Arbor's Ecology Center is thriving, while only two of the other ecology centers still exist. This article posits that a key to this success is the organizational and leadership structure that the Ecology Center employs-a structured egalitarian model that focuses on respect and empowerment of staff and stakeholders. In this article, we analyze the history of the Ecology Center and environmental non-profits through the lens of organizational and leadership structure, drawing out key lessons for the future of the environmental/sustainability movement. The primary lesson is that the alignment of organizational structure and mission is key to achieving successful outcomes. As an organization that bridges traditional environmental non-profits, radical alternatives to traditional organizations, and local action groups, the Ecology Center provides a vivid example of how an organizational structure can adapt and change with the times and pressures, yet retain the key elements that drive organizational mission-based success. Specifically, the Ecology Center demonstrates 
the importance of "Playing Big While Being Small," the critical role of situational leadership, the power of programmatic and tactical fluidity, entrepreneurship as a strategy for growth and innovation, the power of collaboration, and how connection to place enhances organizational effectiveness.

\section{Introduction}

On March 11, 1970, the University of Michigan held the first major Earth Day celebration, drawing over 50,000 participants and helping launch Earth Day celebrations around the country and world (Rome 2013). Organizers used leftover funds from the event to create the ENACT (Environmental Action) Ecology Center, an independent non-profit organization. (Note: over time, the organization has undergone several name changes. For the sake of simplicity, we use the current namethe Ecology Center-throughout the article.) This action was not unique-ecology centers were formed across the country. However, all but three have shut their doors in the past 44 years. As Professor John Edgren observed, "There were a lot of organizations that got started by Earth Day, and a lot of them fell by the wayside. The thing about the [Ecology] Center is that it hung on, and I'm not sure why" (Gates and DeSimone 1985). This article posits that the Ecology Center not only survives but also thrives because its organizational and leadership structure has facilitated the growth and evolution of its mission-based programs. The Ecology Center is a microcosm of the environmental movement; thus, this example presents lessons applicable to the larger environmental and sustainability movement.

\section{Methodology}

Primary research for this analysis involved three methodologies: (1) an archival search, (2) semi-structured interviews with current and former employees of the Ecology Center, and (3) personal experience. This multi-modal approach was ideal because this research is largely exploratory, with no known quantitative studies upon which to base measurements.

First, the authors and research assistants conducted a detailed archival search at the University of Michigan's Bentley Historical Library collection on the Ecology Center (19 boxes of files covering 1970-2010), analyzing board minutes, annual reports, strategic plans, by-laws, and other key documents on organizational struc- 
ture, decision-making, and processes. The search was designed to develop a historical record of staffing, budgets, and organizational structure, as well as insights into how the organizational and leadership structure was implemented and perceived by stakeholders.

Second, the research team conducted a series of interviews with current and former Ecology Center employees and stakeholders. Interviewees included current Ecology Center Director Mike Garfield (1987-present), Research Director Jeff Gearhart (1995-present), Environmental Health Program Director Tracey Easthope (1990-present), former executive director Mike Schechtman (1971-1973), former program director Tom Blessing (1973-1976), former staff coordinator Jim Frey (1980-1986), and former organizational consultant Jim Crowfoot (1977-79). Following the model of Aberbach, Chesney, and Rockman (1975), these semi-structured interviews were "open-ended and the discussions were often wide-ranging" with a "conversational" style in order to elicit "thoughtful" and "complex" answers. The interviews were designed to fill in gaps from the archival record and ground-truth the archival organizational materials with reflections and analysis about organizational culture, structure and function.

Finally, lead author Mike Shriberg worked for the Ecology Center from 20072010 as the Policy Director and engaged with the organization before and after this period as a coalition partner, volunteer, and consultant, recording experiences and observations throughout. As described by Lincoln (1985), this participant observation research approach emphasizes the study of phenomena in their natural setting through open-ended, qualitative processes. All methods were designed to answer the following basic exploratory questions: How was the Ecology Center organized over time? How did this organizational structure contribute to or divert from the achievement of the mission? How does the Ecology Center compare to other environmental non-profits?

\section{0: Earth Day and the Formation of the Ecology Center}

In the 1960s, the American environmental movement reawakened: Rachel Carson's 1962 publication of Silent Spring became a national bestseller and sparked a conversation about the dangers of pesticides, and the environmental movement gained significant momentum (Coglianese 2001; Lear 2009). This environmental renaissance culminated with the first Earth Day on April 22, 1970. Earth Day was conceived by Senator Gaylord Nelson of Wisconsin and staffed by a small group of 
organizers with a total budget of $\$ 190,000$ (Kline 2011). The results were tremendous: 20,000,000 Americans-from over 10,000 primary schools and 2,500 colleges in over 1,000 communities - all rallied under the banner of environmental action (Rome 2013). Earth Day 1970, still known as the largest mass demonstration in United States (U.S.) history, launched the modern environmental movement. In fact, it was during the run-up to Earth Day that commentators first spoke of the "environmental movement" (Rome 2013, 9).

Ann Arbor and the University of Michigan (UM) hold a special place in this history due to a scheduling coincidence. Because UM's academic schedule dictates that finals fall in late April, the first campus organizers, from a student organization called ENACT, decided to move the local event up to March 11, 1970. As a result, UM and Ann Arbor held the first major celebration. An estimated 50,000 people came together at events that spanned 4 days and 124 activities, filling the basketball arena and many academic buildings. Events included: talks by the governor and many other political figures; a teach-in; a U.S. House of Representatives hearing; theatrical performances; workshops on Republican perspectives on the environment; and much more (Kline 2011; Rome 2013). Because it had such strong participation and offered a chance to preview the upcoming official Earth Day, the event drew widespread national and international media attention and is credited with empowering and inspiring organizers in thousands of other communities to implement major celebrations (Rome 2013).

Earth Day was organized at the grassroots level. Existing conservation and environmental groups (e.g., Sierra Club, Audubon Society, National Wildlife Federation) were caught off guard and played little to no role in Earth Day: "Still preoccupied by traditional land and wildlife preservation issues, most of the old guard in conservationism ignored the growing national anger over pollution and other environmental threats to human health" (Kline 2011, 91). However, these groups-referred to collectively as "traditional environmental organizations" throughout this paper-would be deeply affected by the Earth Day momentum and movement.

At UM, ENACT was so successful that it raised over $\$ 70,000$ and had unspent funds. The ENACT organizers, along with a group of Ann Arbor citizens, decided to use the funds to "provide a focal point for local activism" and founded an independent environmental non-profit now known as the Ecology Center of Ann Arbor (EC) (Rome 2013, 5). According to the EC's first Annual Report (1970), "The ENACT Ecology Center was founded in Ann Arbor to meet the need for responsible environmental action, and to provide continuing education on ecological issues." Its purpose was "to provide a community for environmental activities ranging 
from information and education to action, demonstration projects and lobbying for legislation" (Ecology Center 1989). An original flyer from ENACT highlights the organization's "extensive library and reference files" and calls the organization a "catalyst to bring together all segments of public concern for the state of the environment" (ENACT 1970). By 1971, the organization had changed its name to "Ecology Center of Ann Arbor," a choice that reflected "a very intentional statement to communicate the ever-deepening relationship between the organization and the community" (Schechtman 2014). The Ecology Center remained deeply connected with the University of Michigan (as it is today) and many UM stakeholders, but it has never been formally affiliated with the ENACT student organization or with the University.

More than 20 ecology centers opened by the end of 1970 (Rome 2013). Ecology centers varied in form-some ran as stores, some as grassroots activism centers, and some as policy-oriented non-profits-but all were committed to exposing the current environmental crisis and advocating for direct action. Programs were invariably local but with an eye toward global issues and national policy, forming a bridge between traditional environmental organizations that focused on conservation and land protection and local groups that focused on a single issue or geographic area. This bridge in function also created a bridge in organizational structure and leadership.

\section{0s: The Ecology Center Establishes a Form}

The early 1970s were a time of explosive growth in the environmental movement and of unprecedented environmental action at the national, state, and local levels (Kline 2011). Within the movement, mainstream organizations broke away from the more radical alternative organizations. Well-established organizations such as the Sierra Club remained substantially the same as they were in the 1950s, but their staffing grew tremendously, often doubling within the decade (Kline 2011, 96). Their organizational structures tended to be hierarchical, and these traditional environmental organizations worked "within the established political and economic systems" (Kline 2011, 97), growing "more professional, increasing both the size and the specialization of their staffs and shedding their 'amateur status'" (Coglianese 2001, 17). Critics contend that this professionalism doused the Earth Day fire of activism: "The major environmental organizations began to turn into more professional and down-to-business operations than at any time in the past, predictably with mixed consequences" (Sale 1993, 35). 
The alternative, sometimes more radical groups tended to have grassroots status and structures, with leadership often unclear. Efforts were typically communitybased, attempting to enlist public support directly (Kline 2011, 100). Encouraged by activists like Ralph Nader and Barry Commoner, these groups applied professional expertise and organizational skills to specific environmental issues, often using direct action such as protests. Given their small size, they relied on coalitions, exchanges of information, and sharing of resources. Their ability to react quickly to local concerns was predicated on a more open, loose structure and leadership, although this often led to high staff turnover.

The Ecology Center was finding its form and structure in the 1970s, with a professional staff that ranged from three to ten people (Ecology Center 1990). At the end of its first year, the EC had six paid staff and a total payroll of \$8,000 (Ecology Center 1990). Soon thereafter, with the hiring of a second executive director, the entire original Board of Directors was replaced (due to "burnout" after the teach-in) (Schechtman 2014). The original structure of the EC was fairly conventional and hierarchical, with an executive director who had direct hiring and firing authority, among other responsibilities, and staff with formal titles and responsibilities (Schechtman 2014; Blessing 2014). The Board of Directors was very engaged, and the organization made "extensive use of volunteers, interns, work study students, etc." (Schechtman 2014). In an unusual twist, the Ecology Center employed an MBA (Cecil Ursprung) from 1971 to 1973 . Ursprung not only helped set up the books early, but also helped plan staff and board meetings and was able to interact with politicians, corporations and others from a business perspective (Blessing 2014). As the program work expanded and diversified, both staff and volunteers wanted to have more input into decisions (Schechtman 2014; Easthope 2014). Some in the organization had suspicions about specialization and hierarchy, including the potential role of support staff (Easthope 2014). Therefore, the EC brought in a new UM professor to establish a "structured egalitarian workplace" based on the perceived values of the staff, Board, and community (Crowfoot 2014).

In a major shift in direction as a result of this new structure, in 1979, the EC Director started referring to himself as the "staff coordinator," while the staff members considered themselves fairly autonomous and task-driven (Blessing 2014). This "consensus model" featured informal leadership as well as a staff coordinator who helped organize activities. The idea was rooted in the social advocacy movement and involved radical democratic participation by staff. The staff coordinator sat on the Board of Directors and was a spokesperson in the community but ceded the hiring and firing authority of a traditional manager (Garfield 2013). This was controver- 
sial, as some staff preferred the more direct and clear approach, calling the egalitarian structure "unwieldy and unnecessary" and good at "tying [the organization] up in knots" (Blessing 2014). At this first turning point, the organization attempted to align its structure with its work and mission, and part of this structure remains to this day.

The Ecology Center's programmatic work was very successful during this period and included events such as river cleanups, film festivals, community teach-ins, the launch of an organic garden and the still popular Project Grow, and seminars on eco-friendly behaviors (Ecology Center 1970, 1971, 1979). From its first year, the EC provided services such as a library, bookstore, switchboard, newsletter, radio program, recycling drop-off station, and information retrieval (Ecology Center 1970). Projects included a community teach-in, seminars, research and publications, park cleanups, and an "art-in" (Ecology Center 1970). The Center's thinktank orientation began during this time, as it published and widely distributed the Ecology Center Reports. The organization began work in linking environmental and social change by helping develop a successful public transit system in Ann Arbor, catalyzing a local foods movement, and engaging on national issues like the Clean Air Act-including testifying to Congress (Frey 2014). The organization had a "one big happy family feeling" that facilitated the enactment of multiple programs and the freedom to explore new areas for work (Ecology Center 1984). Staff tended to work across program areas rather seamlessly, without extreme specialization or professionalization. Moreover, the work was deeply rooted in Ann Arbor, and the Ecology Center became a symbol and pillar of the community with a deep well of community support and engagement.

\section{0s: Political Crises and Organizational Expansions}

The election of Ronald Reagan represented a political shift that created crises for the environmental movement. The federal government cut funding for environmental organizations and moved against key environmental policies (Coglianese 2001). In part because of these bold moves that ran counter to public opinion (in 1988, over ninety percent of Americans were comfortable calling themselves environmentalists), the environmental movement grew significantly (Coglianese 2001). By 1990, an estimated 12,000 local and regional environmental groups had been established (Coglianese 2001). Traditional environmental organizations "went through a not so subtle and perhaps inevitable process of institutionalization, settling into large 
buildings, large staffs, and large budgets. . . . All [organizations] installed new administrators, all of them managerial types such as lawyers, corporate executives, or bureaucrats, and all at six-figure salaries — in each case brought in from the outside and with a new emphasis on management, personnel skills, and budget balancing" (Sale 1993, 54). While the scale of this transition and these organizations pales in comparison to those of other non-profit sectors and even small corporations, this restructuring and expansion pushed many organizations more deeply into traditional, hierarchical structures.

As mainstream environmental organizations continued to expand their operations in Washington, more radical and grassroots environmental organizations entered the fray. "As one of the EF! (Earth First!) founders, Dave Foreman, noted, "the environmental groups were becoming indistinguishable from the corporations they were supposedly fighting' and there was a need to 'spark . . . a fundamentalist revival within the environmental movement" (Purkis 2001). Foreman argued for a loose network of autonomous individuals pursuing direct action under an anarchistic system so as not to become "them." "With such forthright militancy, EF! succeeded in attracting a considerable following and by the end of the decade had grown to more than seventy-five chapters in twenty-four states" (Sale 1993, 66). This grassroots approach formed largely in reaction against the "cooptation' of the mainstream at a time when the [environmental] perils seemed to be multiplying and the national leadership unresponsive. Among the charges that [grassroots organizations] leveled was that the old organizations were too legalistic, too professional, and too limited" (Sale 1993, 61).

The EC's organizational structure remained somewhere between that of the traditional hierarchies and the loose networks of other environmental non-profits. Early in the 1980s, EC decision-making on daily operational matters was handled mostly on an informal basis through staff operations meetings, yet "an imbalance in the levels of assertiveness in the staff [had] an impact on the formal decisionmaking process" and "the Center [lacked] a formal system of monitoring undone tasks" (Ecology Center 1984). There were no real managers: "mentorship power" was the most prominent form of persuasion and influence. Jim Frey (2014), the staff coordinator for much of the first half of the decade, describes coming to the organization as "instantly becoming a peer because of the organic structure." At that time, the Center was moving toward the implementation of a formal yearly and long-term planning process, using the Board, Board Committees, and the staff 
evaluation committee. All staff members received the same (low) pay, hiring and firing decisions were made by consensus, and everyone designed his or her own peerreviewed "work agreement." This early version of what is now commonly referred to as a 360 review was very innovative at the time. The focus then, as now, was on what an employee needs to be successful, rather than on performance problems (Gearhart 2014). It was possible to raise questions and put employees on probation (Easthope 2014), but this was rarely done, in part because all hiring and firing was performed by committee without clear lines of authority or trained management personnel.

In 1981, the EC (including the EC's own Home Energy Works weatherization service) merged with Recycle Ann Arbor. As a result, the staff became larger and more diverse (e.g., it now included truck drivers and building engineers), with a significant direct service orientation. In 1987, the EC hit an early peak of 34 staff (Ecology Center 1990), with virtually all of the growth occurring in the recycling programs. This growth helped raise EC's stature and visibility in Ann Arbor, deepening connections with volunteers and many other citizens. However, in part because of this relatively large and diverse staff, in the early 1980s, there was discontent with an imbalance in the assertiveness of staff members; lack of formal training for the board; lack of oversight for (self-)evaluations; lack of formalized job descriptions; too many responsibilities; and general burnout and high turnover among staff (Ecology Center 1984). As a result, the egalitarian structure was more formalized. A 50-page "policies and procedures" manual was "followed carefully," and decision making was "highly structured" (Garfield 2013). The staff coordinator took on a larger role and the organization become more professionalized, forcing "staff members to plan and coordinate their activities in a more organized, and perhaps less 'personal' way" (Ecology Center 1984). While many staff appreciated this change and understood it to be part of growth, the 1984 internal organizational analysis (Ecology Center 1984) also recounted opinions that "the 'one big happy family' feeling [was] replaced with an allegiance to particular programs as the programs [increased], which [necessitated] more specific job descriptions." Overall, the emergence of the recycling service as a dominant activity changed the organizational agenda. For example, seeing to operational issues, such as ensuring that recycling pickups were made, began to conflict with attending mandatory staff meetings. This led to "consensus minus one" decision-making and other gradual changes (Frey 2014). The organization also introduced a small pay differential (Garfield 2013), which represented a significant symbolic change in its egalitarian structure. 
1990s: Expansion of goals, emergence of climate and organizational crises

With George H. W. Bush declaring himself the "environmental President" and Earth Day 1990 involving 200 million people in 140 countries, the 1990s started strong for the environmental movement (Gottlieb 2005). The traditional environmental organizations organized the 20-year anniversary of Earth Day largely as a general "Earth Education" media and messaging event that lacked protests and focus. According to Gottlieb (2005), "the broad and unfocused nature of the event also underscored the failure to address the gap between alternative and mainstream groups, a gap that had become more pronounced than ever" (263). By the start of the Clinton Administration, "the professionalization and institutionalization of the mainstream groups seemed secure, though incomplete" (Gottlieb 2005, 216). However, the promise of the Clinton Administration (including Vice President $\mathrm{Al}$ Gore) and the insider tactics of the mainstream organizations did not live up to their potential. Online activism began to emerge and open up the movement to more people (Kline 2011). The rise of the environmental justice movement had a profound influence, creating grassroots splinter organizations that focused on social issues.

The Ecology Center followed a similar path to the broader movement in the 1990s, the first few years of which were fraught with organizational tension and fiscal dangers. These challenges occurred primarily within the recycling arm of the organization, which suffered from poor management and a decline in volume and value of recyclables. After much debate in the 1980s, Recycle Ann Arbor (RAA) became a subsidiary of the EC, even though it employed more staff and had a larger budget than the rest of the EC combined. This change helped to shield the Ecology Center from fiscal problems and allowed RAA to have its own separate, more conventional management structure (Garfield 2013). RAA's hierarchical structure began to mirror that of traditional environmental non-profits. The Ecology Center's Board of Directors appointed members to a separate Board of Directors for RAA. Soon after the separation, the City of Ann Arbor moved from monthly to weekly curbside collection, which doubled the size of RAA's workforce and budget; it also put increasing pressure on the finances of both RAA and the EC (Garfield 2013). The EC Board then loaned RAA money to settle accounts with creditors and the City of Ann Arbor, and it forced the replacement of RAA's manager (Garfield 2013). These events nearly pushed the entire organization into bankruptcy; thus, the EC Board began to play a very active role in the organization, which led to EC 
staff resentment about the Board's influence and methods. In the face of financial pressure, poor management, and Board action, RAA employees unionized (into the United Auto Workers). In turn, the Board blamed the EC's and RAA's financial problems partly on the egalitarian structure, which they tried to change at the EC by hiring two "Directors" and firing two key employees. This led the EC staff to unionize, too (Garfield 2013).

While unionizing alienated some of the board members, it created solidarity among staff, maintaining strong autonomy and formalizing some structural processes. Unionization helped solidify the EC's inclusion of justice and socio-economic concerns into environmental issues, a feature of the organization from the beginning (Crowfoot 2014). Programmatically, the affiliation with the union worked well for the EC's efforts, helping it to build bridges with the labor movement and carve out a niche with an early environment-labor coalition (Garfield 2013). However, the Board continued to have concerns about the loose EC organizational structure; in the 1996 Program Review, the Board made the following comment: "Organization seems like a group of consultants doing great work, raising most of their own money, but it leaves the organization unable to change direction quickly if conditions merited it" (Ecology Center 1996).

Another major result of the separation of the Ecology Center from RAA was that the EC parent organization could devote more attention and resources to advocacy, allowing the EC to move more deeply into a regional approach while maintaining a strong local connection. According to the 1993 Annual Report (Ecology Center 1993), "Through its first 20 years, the Ecology Center focused many of its efforts on developing environmental solutions for the Ann Arbor and Washtenaw County area. Realizing that solutions at home won't happen without being actively involved in related issues throughout our region, [the EC] broadened [its] efforts. Local pollution, waste management, and land use issues are inextricably bound up in statewide and regional issues." As staff members gained experience and joined coalitions, the organization's agendas became larger (Easthope 2014). The outcome of the RAA/EC separation perhaps most relevant to organizational decision-making was that the smaller number of employees left at the parent organization were credited with ensuring that "the egalitarian workplace structure survived" (Garfield 2014). EC employees felt that the larger, more diverse workforce of RAA, as well as the demands of operating a service requiring timely truck service, was a threat to the flat structure; they feared that it might force the EC to function more like a traditional environmental non-profit and less like a grassroots organization. A management team of three people became co-coordinators of the EC, with Mike 
Garfield, the current EC Director, among them. This lasted approximately one year, after which Garfield became sole staff coordinator.

Throughout the 1990s, the formal workplace structure remained flat, a democratic workplace model with "lots of rules and structures to it" (Garfield 2013). Hiring was managed by all employees and accountability upheld via jointly created work agreements and by the Board of Directors, with the staff coordinator acting as the liaison between the staff and board. In the late 1990s, the title of "staff coordinator" was changed to "Director," in large part because this title was recognizable to those in the outside world, including funders, businesspeople, and elected officials. Additionally, the equal pay policy was further adjusted in the mid-1990s to insert differences based on seniority and expertise but not merit (Easthope 2014), with the goal of retaining staff members who could create careers at the EC. This change was extraordinarily successful: a core group of staff remained through the 1990s until the present, breaking the previous trend of a maximum of five years of employment and creating an expertise-based model with high levels of staff autonomy.

\section{0-2009: Rise of Climate Movement}

During the 2000s, environmental groups lacked leverage in Washington in the face of strong conservative political forces; public concern also shifted away from environmental issues following the terrorist attacks of September 11, 2001, and the financial collapse of the latter half of the decade (Kline 2011). Moreover, environmental opposition grew with the ascendance of well-funded property rights and wise use groups, and the Republican Party began to take a codified adversarial stance against climate action, the U.S. Environmental Protection Agency (EPA), and most forms of environmental protection. The anti-environmental national agenda of George W. Bush clashed with increasingly clear prognostications about the dangers of climate change. In 2008, environmental issues did not factor significantly into the electoral landscape, or, despite Barack Obama's strong acceptance speech, into the President's early agenda. The landscape was difficult for some traditional organizations with conservative membership bases like the Audubon Society and National Wildlife Federation. Not only did these groups lose influence and membership, but the political climate in Washington also meant that they had to direct resources at more levels of government as well as at the grassroots level. This change in tactics - coupled with the advantages of increased Internet advocacy — again led to opportunities for grassroots and local groups, which were nimble enough in structure 
and connected enough with local communities to overcome the national political barriers to strengthening support for environmental progress.

In response to these forces, the EC slowly but steadily increased its national and international focus and recognition as well as its staffing in the first decade of the 2000s. For example, the EC was strongly tied with the most significant environmental achievement of President Obama's first term: increasing the Corporate Average Fuel Economy (CAFE) standards (i.e., gas mileage requirements) for cars and light trucks. In addition, the HealthyStuff.org database, which the EC launched during the 2007 holiday season, brought it national renown: the testing of children's toys and products was featured by Fox News, CNN, Reuters, CBS, The Wall Street Journal, The Washington Post, The San Francisco Chronicle, and according to EcoCenter staff, there were "'over $200 \mathrm{TV} /$ radio stories over the [first] 24 hours, [airing] in nearly every market in the US, both large and small. ... On its first day of existence, HealthyToys.org received more than 5.6 million 'hits,' over 1.8 million page views and 100,000 unique visitors" (Mouko 2014). Instantly, the EC's email list jumped from approximately 10,000 to over 100,000. During this time, the Ecology Center led a significant effort and won a hard-earned victory to establish a greenbelt in Ann Arbor, increased Michigan-based organizing around waste issues, significantly increased work around environmental health and toxics (including founding the Michigan Network for Children's Environmental Health), and reentered food-based work. In particular, the greenbelt initiative to keep undeveloped and agricultural land intact kept EC rooted in Ann Arbor politics and policy even as its programmatic reach expanded across the region and country. However, these successes once again strained the EC's flat organizational structure and collaborative decision-making processes, as did the growth of the staff to over 20 full-time employees at the parent organization and over 40 at RAA.

The first major structural change was to establish "associate" positions, whereby young new employees would have a direct supervisor for their first two years of employment and were prohibited from joining the union until after this probationary period. This change recognized the reality that staff members were starting at experience levels ranging from nearly zero to long careers in advocacy (Easthope 2014), and it altered the power structure of the organization. However, it did not completely alleviate new staff members' lack of clear direction when they entered the egalitarian, expertise-based work environment of the EC. Moreover, the Director's lack of formal hiring and firing authority and budgetary control strained the now-larger organization. The growing non-programmatic (administrative) staff members began to feel as if they did not have equal status with the program staff. 
Finally, with this growth, the Director's "brain couldn't handle the amount of communication and management. It was a set of unfair demands" (Gearhart 2014). The EC does not have traditional support staff, and all recognized that there were simply too many processes for any one person to manage (Easthope 2014). Communication breakdowns were rampant. Therefore, after much deliberation and input from consultants and the Board, the EC underwent a significant change in 2010. The staff was organized into three strategic units (Environmental Health, Energy and Climate, and Core Services). Each unit had a representative on a newly formed "Coordinating Committee" (C-Team), which also includes the Director. The CTeam is responsible for strategic direction, budgets, hiring and firing (although the union rules also play a major role), and organizational responsibilities that were previously dispersed through the organization or concentrated solely in the duties of the Director or Financial Director. Staff members have mixed feelings about the impact of this major change, but many feel that the C-Team has democratized and clarified the decision-making authority. It created a structured forum for communication as well as a mechanism for attending to critical organizational functions. The Board plays a more traditional role in setting policy and strategic guidance, but it does not engage in day-to-day management or give regular input into hiring and firing. Overall, many elements of the collaborative, egalitarian structure remainsuch as lack of formal supervisors after the Associate level, community decisionmaking on budgeting, and 360 reviews - forming the hybrid structure currently in place at the EC.

\section{1- Present: Rise of 350.org}

The last several years have seen a continuation of the trends of the early 2000s, with two significant changes. First, the rise of the Tea Party and associated corporatefunded think tanks, combined with the Citizens United Supreme Court decision that allows unlimited independent expenditures in elections, have led to an increasingly emboldened, politically connected, well-funded anti-regulatory movement that denies the existence of climate change. Republican candidates best embody this shift, as acknowledging the reality of climate change is now against party doctrine. Second, traditional environmental groups were challenged from within the movement by Bill McKibben's 350.org. Now the most powerful climate organizing entity, 350.org is leading previously unprecedented numbers of demonstrations 
and largely setting the public agenda on climate action over the resistance of many groups that had been working on climate issues for decades. Structurally, however, the organizational and leadership structure of mainstream and grassroots organizations has changed minimally over the past several years. Some observers believe that environmentalists have become too professional and have lost some of the "fierce green fire" that inspired the movement in earlier decades: "it is a career now, not a mission. As David Brower said, the world is burning and we are playing violins like Nero" (Michael Frome in Shabecoff 2003, 283).

Many early leaders returning for the Ecology Center's 40-year anniversary reflected upon how the EC's organizational and leadership structure had changed over time, yet retained core elements. The transition to the C-team was a hot topic for discussion, particularly since these changes came just prior to another round of significant challenges to the organization. In 2011, another subsidiary organizationEnergy Works - lost its primary grant when an industry lawsuit challenged the state program that housed it. Moreover, RAA had another fiscal crisis, brought on by the low commodity prices of recyclables during the Great Recession, as well as the poorly timed acquisition of a deconstruction company (i.e., one that recycles and reuses construction materials) just as the real estate market crashed. The struggling Michigan economy and national fiscal crisis also drove down grant giving to the parent organization, thereby compounding financial woes. These fiscal challenges led to the first staff cutbacks for budgetary reasons in over 20 years. Despite these challenges, however, the EC hybrid organizational structure survived and thrived. Recently, the EC has re-engaged on the local level. For example, it leads a very active AnnArbor350.org organization, opened a Detroit office focused on environmental justice, is once again highly involved in Ann Arbor-region transit issues, has two staff members devoted to local foods, and merged with a southeast Michigan-based environmental health organization (Local Motion Green). Despite these changes, current staff members still describe the organization as being like a family that values collective responsibility and individual initiative. One big challenge the EC faces is raising staff salaries across the board so that the new generation of EC staff will have the potential for longevity that the core staff has enjoyed (Gearhart 2014). Keeping the difference in salary between the director of the organization and lowest-paid staffer to an uncommonly low level has had a major positive impact on the culture and feel of the EC (Easthope 2014). The EC has been successful at attracting and retaining innovators and change agents, in part because of this communal feel and the freedom to think big, make changes, and feel respected. 


\section{Lessons for the Sustainability Movement}

The key challenge that the Ecology Center case study addresses is how to effectively structure environmental organizations to maximize effectiveness in the face of an ever-changing social landscape. The EC has been remarkably effective as an organization, surviving and thriving despite tough odds, in part because of its organizational and leadership structure. EC is a classic "SPIN" organization, defined by Gerlach (2001) as one that thrives not when pushed to the extremes of bureaucracy or chaos, but when they are Segmentary (composed of many diverse groups), are Polycentric (having competing leaders and centers of influence), and have Integrated Networks (networks with multiple linkages). The EC's "structured egalitarian workplace" idea has been adapted over time but remains a core principle today. Many environmental non-profits across the country have expressed interest in how the EC has been structured, as they have struggled to create their own organizations that maximize talent and resources (Easthope 2014). For these organizations and others, the EC offers six key lessons:

"Playing Big While Being Small." This phrase—used in various forms by several interviewees - refers to the advantages that smaller, nimbler organizations have over traditional organizations. The EC has been able to "play" on the national stage because its organizational structure creates high levels of responsibility, expertise, and collaboration, thus maximizing the organization's potential for influence while using minimal resources. The Healthystuff.org project demonstrates this: with no additional resources at the outset, the EC bootstrapped a toxics testing project into a major force in changing the market for non-toxic products. This innovation was nurtured by the EC's hybrid structure, which allows for autonomy and collaboration within a supportive structure. This structure and the shared leadership model have allowed the EC to avoid the narrow focus of a classic bureaucracy as well as the lack of diversity that has plagued traditional environmental/conservation organizations. In this time of scarce resources and ever-increasing demands, "playing big" through this model is becoming increasingly important for environmental organizations of all types.

Deploying Situational Leadership. The EC hybrid structure requires situational leadership-leadership that is task-dependent and adaptive to the situation (Hersey and Blanchard 1969) — at all levels. Part of the EC's success has been its extraordinary ability to retain top-level staff even in the face of competing offers, low salaries, and extremely rigorous demands on time. The EC's strong reputation is built around these core staff. While burnout is always a factor in non-profit organizations, the 
EC's flexible, versatile structure promotes ownership of issues and programs, which in turn builds deep commitment and capacity in the organization. The "amoeba" structure requires creativity, passion and a spirit of entrepreneurship that can be lacking in hierarchical organizational structures as well as in purely grassroots structures. There is neither strong direction "from above" nor any expectation that staff will follow one particular methodology or pathway. Staff members rarely move on to greener pastures within the field, in part because this flexibility gives them the ability to create and expand their roles within their own organization. The EC's strong reputation for high-quality work and extraordinary staff is founded upon this base. As Gearhart (2014) mentions, "the culture values and fosters innovation and personal growth and development," which makes the EC a "place where people will succeed" and are "valued for the skill set they bring to the table, rather than what they don't have." This has led to the creation of service programs, grassroots campaigns and business partnerships all within the same organization. However, this structure does not work well for everyone: employees who enter the organization expecting and needing a clear hierarchy and well-defined lines of authority have not been able to integrate into the "amoeba-like" EC structure (Garfield 2013).

Power of Programmatic and Tactical Fluidity. The EC hybrid structure also leads to flexibility within issue areas, tactics, and spheres of influence. It is rare for an environmental non-profit organization to operate effectively at multiple scales-from local to international - with multiple tactics and core competencies. In just the past year, for example, the EC led a successful ballot initiative on transit at the local level, advocated for state-level executive action on toxics reduction, released several reports focused on market transformation in several industry sectors, formed partnerships with hospitals and health systems, helped define green purchasing for the major wholesale supply companies in the health care sector, engaged in the national chemical policy reform movement in Washington, D.C. and Michigan, and worked on an international chemical management framework. The EC has accomplished this with a relatively small staff by steadily increasing its professionalism and specialization without losing the passion and connection to the grassroots level (Easthope 2014). While the politics and opportunities have changed, the EC has managed to be responsive not only to what is currently politically possible but also to longerterm opportunities. This flexibility has allowed the organization to thrive in different niches where traditional organizations have not had the nimbleness and smaller grassroots organizations have not had the bandwidth or cache. This fluidity stems from an organizational structure that recognizes and rewards individual initiative yet retains a strong sense of community and dedication to the organizational mission. 
Entrepreneurship as a Strategic Imperative. The EC structure has several service organizations and subsidiaries; this has been a high-risk/high-reward strategy. The trials and tribulations of Recycle Ann Arbor have almost financially ruined the organization several times, yet RAA has provided key funding stability and testing grounds for ideas as well as outlets for outreach for most of its tenure. The direct provision of service allows the EC to engage in forums where traditional non-profits or grassroots organizations are typically present, such as trade associations. For example, the EC's formation of two different energy-service organizations has allowed it to establish long-standing ties with energy providers and gain entry into the policy arena not only as an advocate but also as a recognized service provider with direct experience to draw upon. Organizations without this entrepreneurial spirit—and a structure to support it — are more likely to fail, as the experience of almost all other ecology centers shows.

Power of Collaboration. A collaborative approach is part of the cultural DNA of the Ecology Center. EC staff members have a "strong reputation for being powerful collaborators" (Gearhart 2014). For example, the EC has involved volunteers from "routine administrative maintenance to project work" from its inception, which requires a strong focus on collaboration (Crowfoot 2014). While remaining true to its overriding goal of being democratic and participatory, the EC has created more structure and clarity as its staff has grown over time (Easthope 2014). These rules help outline the terms of collaboration both internally and externally, and they provide a basis for positive interactions. The downside is that active bad agents can sabotage processes, and personnel crises can go unmanaged. Collaboration requires good intentions as well as trust and cooperation, since this collaborative mentality is not necessarily an inherent individual trait; it is a skill that is built through practice and organizational support. Within many traditional hierarchical organizations, collaboration is neither encouraged nor rewarded, so employees often do not collaborate well.

Connection to Place. The EC works at levels ranging from the local to the international, yet remains firmly rooted in a particular community. Its identity is strongly tied to Ann Arbor, even though it currently has an office in Detroit, has no formal affiliation with the University of Michigan, and has programs without a particular geographic focus. This "appetite for engaging the community" (Schechtman 2014) has not faded over the years. Connection to place matters in staff identity, program formation and implementation, fundraising, attracting and retaining staff, and organizational structure and leadership. The EC has managed to take full advantage 
of the talents and passion of the University of Michigan students, staff and faculty, while largely avoiding the town-gown divide typical of college towns (Crowfoot 2014). As a current staffer describes it, this localized approach involves "being connected to a place but sometimes having to go far from that place (like international toxics treaties in order to prevent chemicals from entering the Great Lakes) to protect your backyard" (Easthope 2014). Due to their home location and hierarchical structure, the traditional environmental non-profits-many of which are based in Washington, D.C.- often lack a clear constituency and grounding in issues that matter to their stakeholders. Conversely, single-issue or solely localized non-profits often lack the ability to work on bigger issues and address issues at a systemic scale. The structured egalitarianism of the EC has allowed it to stay in close contact with a local community (in which most of its key donors reside) while providing freedom to extend models outside of Ann Arbor.

\section{Conclusions}

Why has the Ecology Center thrived while nearly all other ecology centers created from the original 1970 Earth Day no longer exist? In large part, the answer lies in the EC's organizational structure and leadership. Despite transitions from hierarchy to flatness and eventually to the current hybrid model of a "structured egalitarian workplace," the focus on respect and empowerment of staff and stakeholders has remained constant. Even the young staff members feel empowered and supported. The dynamic tension between a democratic and hierarchical model creates a vibrancy that endures and holds lessons for organizations of all types. The turbulence of the environmental movement has impacted the EC throughout the past 44 years, yet the EC has found opportunities and niches even during times that were difficult for many environmental non-profits. Egalitarianism and the ability to attract and retain highly competent staff have been hallmarks of the EC experience since its inception. The primary lesson for the environmental movement is that the alignment of an organization's structure with its mission is key to achieving outcomes. The Ecology Center of Ann Arbor provides a vivid example of how a structure can evolve and change with the times, yet retain the key elements that drive organizational mission-based success. 


\section{References}

Aberbach, Joel D., James. D. Chesney, and Bert A. Rockman. 1975. "Exploring Elite Political Attitudes: Some Methodological Lessons." Political Methodology 2 (1): 1-28.

Blessing, Tom. 2014. Personal Interview with Mike Shriberg and Hillary Bedeian. Ann Arbor, March 19.

Coglianese, Cary. 2001. "Social Movements, Law, and Society: The Institutionalization of the Environmental Movement.” University of Pennsylvania Law Review 150:85-118.

Crowfoot, Jim. 2014. Personal Interview with Mike Shriberg and Hillary Bedeian. Ann Arbor, February 18.

Easthope, Tracey. 2014. Personal Interview with Mike Shriberg. Ann Arbor, March 11.

Ecology Center. 1970. 1970 Annual Report. Ann Arbor: Ecology Center.

— 1971. 1971 Annual Report. Ann Arbor: Ecology Center.

- 1979. 1979 Annual Report. Ann Arbor: Ecology Center.

- 1984. Organizational Analysis. Ann Arbor: Ecology Center.

- 1989. Outline of Ecology Center History \& Focus. Ann Arbor: Ecology Center.

1990. Staffs. Ann Arbor: Ecology Center.

1993. 1993 Annual Report. Ann Arbor: Ecology Center.

—. 1996. Comments for 1996 Program Review. Ann Arbor: Ecology Center Board of Directors.

ENACT (Environmental Action for Survival). 1970. Ecology Center Opens. Ann Arbor: University of Michigan.

Frey, Jim. 2014. Personal Interview with Mike Shriberg and Hillary Bedeian. Ann Arbor, February 19.

Garfield, Mike. 2013. Personal Interview with Mike Shriberg and Theresa Zettner. Ann Arbor, April 12.

Gates, Max, and Bonnie DeSimone. 1985. "Earth Day Helped Draw Attention to Deteriorating Environment.” The Ann Arbor News, February 5, 1985.

Gearhart, Jeff. 2014. Personal Interview with Mike Shriberg and Hillary Bedeian. Ann Arbor, February 26.

Gerlach, Luther P. 2001. "The Structure of Social Movements: Environmental Activism and Its Opponents." In Networks and Netwars: The Future of Terror, Crime, and Militancy, edited by John Arquilla and David Ronfeldt, 289-310. Santa Monica: RAND.

Gottlieb, Robert. 2005. Forcing the Spring: The Transformation of the American Environmental Movement. Washington, D.C.: Island Press.

Hersey, Paul, and Kenneth H. Blanchard. 1969. Management of Organizational Behavior: Utilizing Human Resources. New Jersey: Prentice Hall.

Kline, Benjamin. 2011. First along the River: A Brief History of the U.S. Environmental Movement (Fourth Edition). Plymouth, United Kingdom: Rowman and Littlefield.

Lear, Linda. 2009. Rachel Carson: Witness for Nature. Boston: Houghton Mifflin Harcourt.

Lincoln, Yvonna S. 1985. "The Substance of the Emergent Paradigm: Implications for Researchers." In Organizational Theory and Inquiry: The Paradigm Revolution, edited by Yvonna S. Lincoln, 137-157. Newbury Park: Sage Publications.

Mouko. 2014. "The Site Seen round the World.” Mouko. June 11. http://www.mouko.com/whatwe-do/case-studies/healthystuff-dot-org. 
Purkis, Johnathan. 2001. "Leaderless Cultures: The Problem of Authority in a Radical Environmental Group." In Leadership and Social Movements, edited by Colin Barker, Alan Johnson, and Michael Lavalette, 160-177. Manchester, United Kingdom: Manchester University Press.

Rome, Adam. 2013. The Genius of Earth Day: How a 1970 Teach-In Unexpectedly Made the First Green Generation. New York: Hill and Wang.

Sale, Kirkpatrick. 1993. The Green Revolution: The American Environmental Movement, 1962-1992. New York: Hill and Wang.

Schechtman, Mike. 2014. Telephone Interview with Mike Shriberg and Hillary Bedeian. Ann Arbor, March 20.

Shabecoff, Philip. 2003. A Fierce Green Fire: The American Environmental Movement (Revised edition). Washington, D.C.: Island Press.

\section{Acknowledgements and Disclaimer}

The authors wish to thank Hayley Sakwa, Theresa Zettner, and Nick Boyd for their invaluable research assistance. We are also grateful to the Ecology Center employees past and present for their time and interest as well as to the helpful staff at the University of Michigan's Bentley Historical Library for their assistance. Finally, thanks to the Graham Sustainability Institute for support of this research. The research protocols for this piece were reviewed and approved by the University of Michigan Institutional Review Board (IRB). All of the participants in our interviews gave us permission to use their names and direct quotations in this piece. 